\title{
1 Foreword
}

\author{
A Voyage into America - \\ Discovering the New Wretched of the Earth \\ John M. Hobson*
}

I had the pleasure of meeting Rajani Kannepalli Kanth back in 2007 at a conference he organized entitled 'Congress 2007' that was held in Salt Lake City over three days. Of the many things and people that struck me at that extraordinary conference was Rajani; a man of few words and those that were uttered were enunciated in a softly, softly manner. However, having already read his book Against Eurocentrism, ${ }^{1}$ and having had the honor of introducing this text to the Conference participants, I already knew that his work is anything but softly, softly, brimming with passion and uncompromising prose. And so it is with the present book.

Probably this book should come with two intellectual health warnings attached: first, that it refuses the invitation of standard academic positivism thereby no doubt offending those academics who rely on such a mode of enquiry; and second, for those potential readers who believe that America is the highest stage of civilization or that it represents 'the end of history', this book will be a painful but necessarily challenging read, to say the least. For a potential academic reader of the present book it is noteworthy that it is not 'blessed' with, or constrained by, the usual kinds of accoutrements that would be expected, nay demanded. There is no primary data - no archives plumbed, no questionnaires undertaken, indeed no 'positivist star' (or 'black hole' depending on one's own set of preferences) that guides the way for the reader to deliver her to the promised 'value-free land' (or 'barren and dark place' depending again on one's own preferences). Nor is this book for the faint-hearted reader and nor was it ever meant to be. It is instead an uncompromising critique of American civilization and its way of life; one that pulls no punches and takes no prisoners. Indeed were Kanth to be asked what he thinks of American civilization today he would no doubt invoke the Gandhian response: 'it would be a good idea'. And, as with the Gandhian response, it would be true to say that it is a critique based on a series of personal, subjective reflections rather than one based on an objective, value-freedom. But does that make it any less powerful?

Some people - either pro-Western sympathizers or self-proclaimed positivists might well describe the book as a 'polemic'; though to the extent that I endorse such a label I do not, however, use it as a shorthand for unoriginal or 'illegitimate' work as it is sometimes cynically deployed by such critics in order to dismiss its various

1 Rajani Kannepalli Kanth, Against Eurocentrism: A Transcendant Critique of Modernist Science, Society, and Morals (New York: Palgrave Macmillan, 2005). 
arguments. Instead it is clear that the author seeks to produce a work that relies more on empathy and imagination rather than positivistic autism and science. As he puts it in the acknowledgements: '[b]ooks, I like to think, are not written... but dreamed, in the phantasms of the vital imaginations that keep us alive'. More specifically, the reader receives the reflections and perceptions of an Indian 'outsider' living as a double-insider - residing both within the Academy and within American society. I place the term outsider in inverted commas because while the author is indeed Indian, he has also lived in the United States for the majority of his life, having arrived there from India at an impressionably young age, and having lived there ever since. This means that he is able to bring extra-Western personal insight into our understanding of America while at the same time being embedded within its norms and culture; reflections that are not gleaned from reading books from afar in an isolated ivory tower but from living there first hand on the ground so-to-speak. To those who would bemoan the book's lack of positivism it might be replied that his preferred methodology is one that plumbs depths that otherwise would remain deep beneath the surface, untapped by the often blunt, unfeeling and unimaginative instrument that positivism constitutes.

Coincidentally, another person whom I had the great pleasure to meet at 'Congress 2007' has recently published a book called Being Different. Such a book also critically reflects on the West by viewing its central philosophy through anti-universalist Indian eyes - specifically Dharmic eyes. ${ }^{2}$ While these two books certainly complement each other and overlap in all manner of ways, nevertheless the present one wraps up its critique of America and the West with a blend of Indian and postmodern/ poststructuralist as well as postcolonial theoretical insight. Rather than offering a specifically Dharmic solution to the problem of Western universalism, Kanth prefers to point up the limitations of American civilization and to either infer a solution or simply invite the reader to contemplate alternatives. The book takes us on a grand tour of the normative or cultural pillars of America, each of which is awarded its own separate chapter even if in aggregate they overlap in a multitude of ways. For underpinning the whole discussion are two key threads - the twin cultural problems of (if I may be permitted some hermeneutic license) 'hyper-individualism' and racism/ Eurocentrism. And it is in this context that I have chosen the particular title for this foreword.

Edward Said, who was of course the famous author of Orientalism, ${ }^{3}$ later on referred to the notion of 'the voyage in' to the West from the East. As he put it: 'The conscious effort to enter into the discourse of Europe and the West, to mix with it, transform it, to make it acknowledge marginalized or suppressed or forgotten histo-

2 Rajiv Malhotra, Being Different: An Indian Challenge to Western Universalism (New Delhi: HarperCollins, 2011). Note that Dharmic religions comprise Hinduism, Buddhism, Jainism and Sikhism. 3 Edward W. Said, Orientalism (Harmondsworth: Penguin, 1978/2003) 
ries... I call this effort the voyage in'. ${ }^{4}$ The present book offers a voyage in to American civilization, though this voyage is rather different to the one that Said navigates. Instead, rather than seeking to reveal the forgotten histories of peoples and civilizations that reside outside of the West and how they have shaped or 'constituted' Western civilization, the author instead seeks in part to probe the forgotten non-white identity of America that was purged by, or exorcized in, the construction of its Self. But it also does a lot more than this. In a key sense, the book is reminiscent of Ashis Nandy's classic text, The Intimate Enemy. ${ }^{5}$ Its central message is that the imperialist colonizers become, as it were, psychically underdeveloped. This is in part a function of the alienation process that goes hand-in-hand with the act of oppression. But it is also a product of the Western identity-formation process and the construction of the Other. For what such a process entails is a removal or 'exorcism' of all things that are deemed to be 'irrational' from the identity or constitution/construction of the Western or American self and which are then projected on to a now imaginary inferior other. Put simply, the East becomes the dumping ground or the sewer into which all the supposed 'impurities' of the Western self are ejected. But in the process, the holistic essence is lost leaving only an alienated Western hyper-individual. Accordingly, the much-needed holistic individual - one which feels satisfied and at one with its 'whole' self as opposed to a fragmented self that is only partial - is lost. Or to borrow the phraseology of the author, in living up to the rigid, robotic sense of an individualized self that is left standing after the purging of its soul, so the American lives a life whereby he or she becomes alienated, limping around on the crutch of a peculiarly materialist culture. Except that what is deemed to be a crutch turns out to be a chain that confines the individual within the prison of alienation and atomization - the very source of the problem that infects all the pillars of American civilization. It is here, then, that we encounter one of the central threads that weaves the text together: specifically the loss that comes from living a hypostasized individualist life that is atomized and cut off from the whole that makes us human. As Kanth puts it: 'the net result of this is an individual who is marred by the thoughts that I don't need to think, because, for a small fee, someone will do that for me. I don't need to create, because the Museum and the Art-Gallery can afford me creators. I don't need to govern, because the professional politician will function for me. I don't need to be entertaining because the record, the video, and the tape will pipe in the vital, if precooked, food for my starved sense. Most of us live thus, reduced, atomized, fragmented, idolized, robotinized, paralyzed of human attributes, turning into critical, unfeeling nuclei of controlled passivity'(from chapter 2).

Although Kanth is clearly no fan of capitalism, particularly in its US-incarnation, nevertheless he is no Marxist. If anything, Kanth leans more toward an epistemo-

4 Edward W. Said, Culture and Imperialism (London: Vintage, 1994), 260-1.

5 Ashis Nandy, The Intimate Enemy (Delhi: Oxford University Press, 1983). 
logical idealism of a poststructuralist or postmodern sensibility, leading him to view culture as ontologically trumping class or economics. In this respect he finds the culture of materiality to be more fundamental than the economic structure of capitalism itself. For it is this culture that infects American capitalism, as much as it is the hypostasized culture of 'great expectations' that fuels a rampaging individualized capitalism. All of which not only leads to an impoverished sense of self or being but one that reflects such a cultural condition in the first place. Americans are, he argues, slaves to a hyper-inflated series of expectations that must be met before the good life can be attained and proclaimed. Anything less is judged to be failure; and failure is deemed to be entirely unacceptable. Coming second in anything is, after all, simply a shorthand for being the 'first best loser'. For Kanth, happiness is measured not by a high per capita income or GDP or any other economistic standard. Rather, the standard of happiness is based on aligning economic outcomes with expectations. When viewed through this lens it is not the aboriginal peoples of the Earth who are impoverished but the Americans who never have enough to meet their reified spending habits, being always short and always wanting more. Accordingly, in Kanth's alternative imaginary it is the American people, or the vast majority of them, who are in a sense the wretched of the Earth and the slaves to hyper-inflated expectations that can rarely, if ever, be met.

It is, of course, at this point that we encounter the second part of the title to this foreword. Here I am playing on the title of Frantz Fanon's famous book. ${ }^{6}$ For Fanon, however, the 'wretched of the Earth' referred to the colonized peoples. Charting how the colonized had, albeit not perfectly, internalized the psychology of inferiority that the colonizers imposed, Fanon's work was a rallying cry to the oppressed to shake off the psychological - as well as political - chains that bind them. Here, and reminiscent of Nandy's approach, Kanth reverses not simply the gaze in a kind of 'reverse Anthropology' as he calls it, but the logic to reveal - again to take some hermeneutic license - the 'new' wretched of the Earth: specifically the American people. Interesting in this context is Kanth's claim that Americans' desperate quest for success in world sport emanates from a profound inferiority complex. No less interesting is that he locates this in terms of the legacy of America's original third world culture and its fight against colonialism. Thus in being captured by the cult[ure] of hyperindividualism so what appears as the land of the free is reimagined as the land of the repressed. Colonialism, I might suggest, has in Kanth's imaginary been reversed so that Americans continue to live a life of repression, except that it is policed and maintained by their own 'inverted' post-colonial culture. And thus Kanth's book is, in effect, a rallying cry for the new wretched of the Earth to cast off their own chains of self-repression so as to move beyond this psychologically impoverished condition into the real land of the free.

6 Frantz Fanon, The Wretched of the Earth (London: Penguin, 1961/2001). 
Moreover, according to Kanth one of the key problems with American society is its pervading propensity for racism. This is something that, he argues, was there at the birth of America. 'For Two Hundred solid years, generations of Africans, human chattel, slaved for their White Masters in America and the Caribbean, an estimated Two Hundred Million worked to death, stripped of all human dignities, severed from family and kin, broken by the leash, the collar, the chain, and the whip' (Kanth, chapter 6). But the legacy very much remains with us today, he insists, rather than constituting a piece of historical knowledge of a by-gone era that is best forgotten. Thus 'it is assumed that blacks are looked down upon because they were slaves, once upon a time; even more true is the proposition that Africans were enslaved because they were looked down upon' (p. 153). Here, he is particularly critical of the role that the Academy plays, lambasting it for maintaining the great lie concerning the supremacy of Western civilization and the concomitant marginalization of the East in the story of world progress. Again, to reiterate the point made earlier: that for Kanth racism is not merely epiphenomenal to an economic system of exploitation - it is, rather, a proactive discourse of prejudice that inter alia guides the economy towards racist ends. Here his poststructuralist leanings differentiate him not merely from the standard Academic apologists but also from Black Marxists who argue that the demands of capitalist economic exploitation necessitate an accompanying ideology that justifies it - with racism being the outcome. ${ }^{7}$ Rather, for Kanth, racism is a debased and debasing culture that infuses materialist structures of power, though it is also the case that such structures fan the flames of this virulent ideology though a kind of elective affinity.

But to close: there is much here that will scintillate and much that will abrade, depending on one's own stance to the question and issue of 'American civilization'. Either way, though, this journey or voyage into America's sub-conscious is one that suggests ways of healing by drawing to the surface that which has been sublimated, even if the method is to psychologically shake the reader rather than hypnotize her. The reader has been warned, let the discursive battle for redemption begin...

^John M. Hobson is the author of The Eurocentric Conception of World Politics: Western International Theory, 1760-2010 (CUP, 2012) and is Professor of Politics and IR at the University of Sheffield.

7 Perhaps the best-known example of this logic is found in Eric Williams' classic book, Capitalism and Slavery (London: Andre Deutch, 1944). An excellent contemporary version is found in Kenan Malik, The Meaning of Race (New York: Palgrave, 1996) 